\title{
El problema de la unidad en la Filosofía griega.
}

\author{
(Fragmento)
}

El problema de la eternidad y del tiempo se conecta de modo indisoluble con el de la unidad y de la variedad. Llegar a lo eterno equivale a alcanzar el reposo, la paz absoluta y final. Y como este reposo, esta paz, sólo pueden obtenerse aboliendo al par todo movimiento, toda discordia, toda contradicción interior, resulta que la accesión a lo eterno debe confundirse con la accesión a la unidad. De hecho al alma le ha parecido siempre que así la perspectiva de lo que aparece y

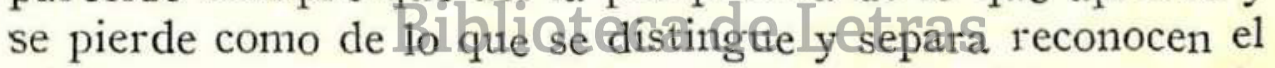
mismo origen metafúsige, Pýl poin elso Clanaspiración a la unidad ha sido siempre una aspiración a la quietud. Y ese origen metafísico consistiría en una inexpresable, misteriosa descomposición prismática de algo que siendo puro, invisible y eterno, se diversificara en las mil cambiantes coloraciones del espacio y del tiempo.

Reintegrarse en la pura inmovilidad, abolirse en ella ha constituido siempre la nostalgia mística del espíritu que consagrando la unidad sin accidentes de tiempo ni de espacio se consume en el anhelo de volver, de retornar a la pureza absoluta de ese principio. 


\section{$-308-$}

Todo el drama de la metafísica griega puede resumirse en el contraste y en la indisoluble unión entre la inmovilidad y el movimiento. Los eleáticos quieren alcanzar el ser eliminando el movimiento y la multiplicidad. Heráclito quiere alcanzar el devenir eliminando toda inmovilidad. Y ni los eleáticos logran alcanzar una noción de lo uno exenta de toda alteridad y de todo cambio, ni Heráclito consigue eliminar del devenir toda huella de unidad y de permanencia. Son dos movimientos que llevan en sí lo que niegan, pero de todos modos representan dos intuiciones, dos anhelos opuestos que se confrontan en una porfía, llena de tensión y de significado a través de la historia del pensamiento griego.

Platón es la conciencia de las dificultades inherentes al eleatismo y al heraditeísno, representa además el conocimiento especulativo de esas doctrinas y su filosofía es, en cierto modo, la síntesis entre la intención eleática hacia lo uno, con todo lo que esa intención implica de inmovilidad y de eternidad, y la intención heracliteana hacia lo vario, con todo lo que ella inonplica dectenmeralidadays de oposición. "Platón, dice Jean «Jahl,phacen eqnino hosenjũos que quieren a la vez las dos cosas entre las cuales se les pide escoger: quiere el reposo de los eleatas, y el movimiento de Heráclito" ( I). Y así el esfuerzo más fecundo y a la vez el más arduo de la filosofía consistirá en introducir la alteridad en lo uno y la unidad en lo múltiple; lo cual, acaso, significa también introducir el tiempo en lo eterno y la eternidad en el flujo temporal de las cosas.

Es en el Parménides, donde podemos asistir al diálogo interior de la problemática platónica, en su forma más aguda. Lo que en el Parménides se impugna es la creencia en

(1) Etude sur le Parmenide de Platón, París, 1926 pág. 144. 
una unidad separada, en si, excluyente de toda alteridad, de todo cambio. Se afirma en cambio la multiplicidad en la unidad y la unidad en la multiplicidad. Pero puesto que de la unidad pueden afirmarse maneras de ser contradictorias, puesto que aparecen más allá del principio de identidad, en el fondo se la concibe como una tensión, como un conflicto. Y así acaso podríamos llegar a Hegel a través del Parménides.

Es una lucha, un drama, pero es evidente también que entre las tendencias que se oponen es mucho más fuerte la que, reivindicando para el ser puro, simple, inmóvil y uno la suprema realidad metafísica, desvaloriza el devenir y considera lo vario como aparente, irreal o a lo menos, como una forma degradada, secundaria e inconsistente de la existencia. Es decir que es la tendencia eleática la que está destinada a triunfar. Y de esta suerte Platón, en cuya obra el problema metafísico del pensamiento griego alcanza su máxima tensión, acaba por superar la inquietud, por resolver o mejor por olvidar las dudas que se transparentan en las paradojas del Parménides y por consagrar en la idea suprema del bien, la umidalindidisibley eterna que los eleáticos proclamaban conjorgensenendäderonverso"

Porque la idea platónica del bien no es la idea de un simple "deber ser" sino que en ella se contiene la máxima afirmación del ser. Y ello es evidente, puesto que atribuyendo Platón a las ideas la existencia y la sustancialidad es natural que una y otra se den por modo eminente en la idea del bien que es la idea de las ideas, aquella que corona y subordina toda jerarquía de los eternos arquetipos.

De modo que la idea del bien asume en el sistema platónico algo así como la suprema dignidad ontológica. Pero es también la suprema unidad, la unidad pura, sin contradición ni negación, y lo es, porque si la idea platónica 
del bien asume la más alta representación del ser o mejor es ella misma el ser absoluto sin ningún elemento que lo niegue, ese ser tiene que identificarse con la unidad pura, excluyente de toda negatividad. Y como esa unidad, encerrada como está en sí misma no puede salir de su estática pureza para suscitar el movimiento y la contradicción del devenir, resulta que Platón concibió el bien más que como un principio como un término, como un punto final en que viniera a expirar la frase temporal de las cosas.

Ese punto final se convierte en el acto puro de Aristóteles. Ese acto puro es la unidad perfecta y el ser absoluto, supremo. Es la unidad perfecta, porque si contuviera algún elemento de oposición o de alteraridad dejaría de ser acto puro. Es el Ser Supremo, porque es una afirmación pura sin ningún elemento de negatividad, la plenitud absoluta, que reposa en sí misma y hacia la cual asciende sin poder alcanzarla, la escala de las criaturas.

$\mathrm{Y}$ en fin, Plotino erige como supremo ideal místico y al propio tiempo como la más absoluta afirmación del ser el Uno Puro, en el cual se subliman juntamente con toda la tradición eleátić, lia ñezcladiedecible de nostalgia y de anhelo, el voto deomomadamientocblel ansia de vida, la fatiga infinita y la elevación hacia la luz en que se consume y exalta el alma crepuscular del helenismo.

$Y$ he aquí como la escuela neoplatónica, que Plotino representa por modo eminente, nos revela el íntimo sentido, el significado fundamental del eleatismo. La unidad eleática, más que la unidad inicial es la unidad que termina, que acaba; un llegar a ser que, obedeciendo a un anhelo metafísico de permanencia, de estabilidad, de reposo, la mente concibe al propio tiempo como el fundamento intemporal de todas las cosas. 
Mientras el eleatismo se aleja del mito, Heráclito permanece todavia en su atmósfera, vive en el círculo mágico de la influencia órfica; por eso concibe la realidad como conflicto trigico, como incesante devenir; y por eso tambićn la simboliza en la imagen del fuego que es la actividad que crea porque es la activiclad que consume y devora. En la muerte y resurreccion de Zagreo, que se recordaban en los ritos de los misterios veía sin duda Heráclito la configuración de la ley eterna que hace de la muerte la indispensable condición de toda nueva vida, en las lamentaciones con que los iniciados conmemoraban el martirio de Dionisos y cn los gritos de jubilación con que saludaban su triunfo veia sin duda la trágica necesiclad de la desesperación y del dolor, y en la atmósfera toda de los misterios recogió quizá la inexpresable sabiduría que, en la alterpacion del nacimiento, de la muerte y del renacer para volver a morir, descubre la invencible inmortalidad de la vida.

La guerra es madre y señora de todas las cosas, es el pensamiento germinal de todo el pensamiento de Heráclito. La guerra, es decir bi buldatediridita, esdecirsla vida en la muerte, la muerte en la vida el ng feren el ser, y la incontenible moviliclad de lo real que parece consumirse en el propio acto cn que se crea.

Platón y Aristóteles confrontan el problema de devenir pero no se detienen en la pura movilidad, animados como están por la tendencia irresistible hacia la suprema unidad que no es únicamente la forma sino la sustancia de lo real. Y así el astro del gran efesio brilla solitario y distante en el cielo matinal de la antigüedad.

Mariano Iberico, 